\title{
KRAS CYS-12 Mutant Protein
}

National Cancer Institute

\section{Source}

National Cancer Institute. KRAS CYS-12 Mutant Protein. NCI Thesaurus. Code C29141.

A synthetic form of the K-ras protein containing a point mutation at position 12 (glycine to cysteine). Vaccines using mutant K-ras proteins may be used in the immunotherapy of various cancers that express mutated K-ras proteins. (NCI04) 